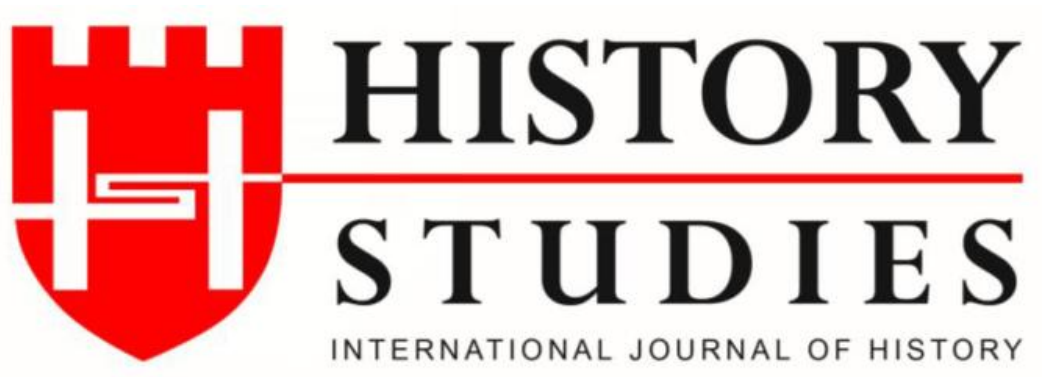

ISSN: 13094173 (Online) 1309 - 4688 (Print)

Volume 12 Issue 4, August 2020

DOI Number: 10.9737/hist.2020.909

Araştırma Makalesi

Makalenin Geliş Tarihi: 23.03.2020 Kabul Tarihi: 26.04.2020

Atıf Künyesi: H. Hale Kozlu - Özlem Sümengen - Seven Gözübüyük, “Geleneksel Kayseri

Hamamlarında Doğal Aydınlatma Sistemleri", History Studies, 12/4, Ağustos 2020, s. 2023-2042.

\title{
Geleneksel Kayseri Hamamlarında Doğal Aydınlatma Sistemleri
}

\author{
Daylight Systems In Turkish Bath Architecture on Kayserı City Center
}

\author{
Doç. Dr. H. Hale Kozlu - Dr. Özlem Sümengen - Dr. Seven Gözübüyük \\ ORCID No: 0000-0001-6711-3139 / 0000-0002-9742-0612 / 0000-0001-7772-4136 \\ Erciyes Üniversitesi
}

Öz: Mimari yapılarda işleve, döneme veya bölgeye göre farklı biçim ve özelliklerde üretilen doğal aydınlatma sistemleri, görsel ve psikolojik konfor durumunun iyileşmesinde önemli rol oynamaktadır. Türk medeniyetinde temizlik, sosyalleşme ve gelir sağlama gibi birçok eylemle ön plana çıkan hamamlarda kullanılan aydınlatma elemanları, mekânsal niteliğin ve konfor koşullarının ayrılmaz bir ögesidir. Hamamların, mahremiyet gereksiniminin yüksek olduğu yapılardan biri olması nedeniyle mekânlarda doğal aydınlatma elemanlarının kullanımı, tasarımın önemli bir parametresi olarak değerlendirilmiş, bu amaçla farklı çözüm önerileri geliştirilmiştir. Mekâna günışı̆̆ı alımında kullanılan ışı/kaydınlık fenerleri, aydınlık pencereleri, ışık gözü-fil gözü, ışı tavanları gibi yapısal çözümler ile atmosfer zenginleştirilmiş, mekân algısında bu aydınlatma elemanlarının önemli bir katkısı olmuştur. Bu çalışma kapsamında Kayseri kent merkezinde yer alan 7 adet tarihi hamamın doğal aydınlatma elemanları belgelenerek, mekânlardaki kullanım yoğunluğu, çeşitleri ve boyutları tipolojik bir çalışma ile değerlendirilmiştir. Böylece bu yapıların doğal aydınlatma çözümleri açısından özgün niteliklerini vurgulayarak mekânsal kalite potansiyellerinin koruma ve yeniden işlevlendirme bağlamında genişletilip geliştirilebilmesine imkân tanınması hedeflenmektedir

Anahtar Kelimeler: Doğal Aydınlatma/ Günışı̆̆ı, Hamam, Kayseri, Koruma

Abstract: Natural lighting systems produced in different forms and features according to function, period or region in architectural buildings play an important role in the improvement of both visual comfort conditions and psychological comfort. In Turkish baths, lighting systems are an integral element of spatial quality and comfort conditions. Since the baths are one of the buildings with the highest need for privacy, the use of natural lighting elements in spaces has been evaluated as an important parameter of the design, and different solutions have been developed for this purpose. Accordingly, structural solutions such as lighting lantern, windows, oculies, light ceilings were produced in daylight intake to the space. These lighting elements made an important contribution to the perception of space. Within the scope of this study, the natural lighting elements of 7 historical baths located Kayseri were documented and evaluated with a typological study. Thus, it is aimed to enable the spatial quality potentials to be expanded in the context of 
conservation and re-functioning by emphasizing their unique characteristics in terms of natural lighting solutions.

Keywords: Daylight, Turkish Bath, Kayseri, Conservation, Traditional Buildings

\section{Giriş}

Anadolu medeniyetinde, mimari mekânları ve teknik çözümlemeleri ile ön plana çıkan hamamlar, inanç ve kültüre göre değişerek kendi özgün özellikleri ile farklılaşmaktadırlar. Özellikle Roma Döneminde sosyal, işlevsel ve teknik altyapı açısından gelişmiş bir mimari yapı türü olarak ortaya çıkan, İslam medeniyetleri içerisinde de gelişip değişerek işlevini sürdüren bu yapılar, her dönemde geleneksel kültürün önemli temsilcileri olmuşlardır. Değişen temizlik kültürü ve konfor şartlarının gelişmesi halk hamamlarının daha az kullanımına yol açsa da, toplumsal geleneklerin ve alışkanlıkların sürdürüldüğü birçok bölgede bu hamamlar hizmet vermeye devam etmişlerdir.

Tasarım ve yapım sürecinde dönemine göre ileri bir teknolojiyle 1sıtma, havalandırma, aydınlatma gibi teknik altyapı çözümlemeleri kurgulanan hamamlarda, mekânların mahremiyet gereksiniminin yüksek olması, aydınlatmanın bu kurgu içerisinde özel olarak ele alınmasını sağlamıştır. Aydınlatma çözümleri, mekânsal ihtiyaçlara ve yapısal imkânlara bağlı olarak doğal ve yapma aydınlatma elemanları ile kurgulanmıştır. Kamusal binalar arasında işlevsel ve mekânsal düzenlemeleri ile farklılaşan bu yapılarda yer alan aydınlatma sistemi ve elemanlarının detaylı olarak incelenmesi, değişimin tespiti açısından önem kazanmaktadır.

Roma ve Bizans Dönemine ait az sayıda örneğin günümüze ulaşabilmesi ve Anadolu coğrafyasındaki yaygın temsilcilerinin genellikle "Türk Hamamı" olarak adlandırılan, İslamiyet sonrası medeniyetlere ait olan yapılar olması nedeniyle, araştırma kapsamına sadece bu yapılar dâhil edilmişlerdir. Anadolu'da hemen hemen her yerleşim biriminde rastlanan Türk hamamlarında kullanılan doğal aydınlatma elemanları incelendiğinde, 1şı//aydınlık fenerleri, aydınlık pencereleri, 1şı gözü/fil gözü ve 1şık tavanları karşımıza çıkmaktadır. Bu açıklıkların yanı sıra bazı mekânlarda kandiller, şamdanlar v.b. yapma aydınlatma elemanlarının da kullanıldığı bilinmektedir.

Geleneksel Türk Hamam tipolojisi içerisinde farklı dönemlere ait örnekleri barındırması açısından Kayseri önemli bir yerleşim birimidir. Özellikle aydınlatma elemanları konusunda detaylı bir çalışma yapılmamış olan Kayseri hamamlarının incelendiği bu çalışmada, kent merkezinde yer alan ve günümüze ulaşabilen geleneksel hamamların doğal aydınlatma elemanları yerinde incelenerek belgelenmiş ve mekânlardaki kullanım yoğunluğu, çeşitleri ve boyutları tipolojik bir çalışma ile değerlendirilmiştir. Bu kapsamda, Kayseri kent merkezinde günümüze ulaşabilmiş olan 7 hamamın, soyunmalık, soğukluk, aralık, sıcaklık ve halvet hücrelerinin aydınlatma yöntemleri incelenerek kullanım yerleri ve formları belirlenmiştir. Bu çalışmanın sonucunda, yapıların doğal aydınlatma çözümleri açısından özgün niteliklerini vurgulayarak, mekânsal kalite potansiyellerinin koruma ve yeniden işlevlendirme bağlamında genişletilip geliştirilebilmesine olanak tanınması amaçlanmaktadır. Bu yapıların aydınlatma çözümlerinde elde edilecek benzerliklerin ve farkl1lıkların mekânsal etkilerinin tespitinin, hem koruma-restorasyon çalışmalarında hem de yeniden işlevlendirme alanında geliştirilecek yeni öneriler için bir veritabanı oluşturması hedeflenmektedir ${ }^{1}$. Özellikle yeniden işlevlendirme projelerinde, öncelikli olarak tarihi yapının özgün mekânlarına ve yapı elemanlarına minimum müdahalede bulunulması ilkesi doğrultusunda, önerilen işleve uygun eylem çeşitliliği, doğru bir

$1 \mathrm{Bu}$ çalışma, Erciyes Üniversitesi Bilimsel Araştırma Projeleri Koordinasyon Birimi tarafından FBA_6066 kodlu proje ile desteklenmiştir. 
aydınlatma tasarımının belirleyicisi haline gelmeli ve hacimde sağlanan aydınlık değerlerinin bu işlevin gerekliliklerine cevap vermesi beklenmelidir. Bu bağlamda, farklı mimari özelliklere sahip olan geleneksel yapı tiplerinin doğal ve yapma aydınlatma sistemlerinin tespit edilmesi ve bu sistemin özgün yapı kurgusu ile bağdaştırılarak yorumlanması, gerek geleneksel yap1 stoğunun belgelenmesi, gerekse yeniden işlevlendirme çalışmalarında doğru tasarım kararlarının alınabilmesi açısından önemlidir.

İncelenen yapıların büyük çoğunluğunun özgün işlevi olan hamam işlevi ile aktif olarak kullanılması ve mahremiyet problemleri açısından,5 yapıların bazı mekânlarında fotoğraf çekimi mümkün olamamıştır. Bu mekânlardaki aydınlatma elemanlarının fotoğraflarında, geçmişte yapılmış olan belgeleme çalışmalarındaki fotoğraflar kullanılmıştır. Kent merkezinde yer alan ve günümüze sadece temelleri ulaşan Gülük Hamamı, üst örtüleri ve duvarlarının büyük bir kısmının yıkılması ve literatürde aydınlatma elemanlarına dair bir bilgi bulunmaması nedeniyle çalışma dışı bırakılmıştır. İncelenen hamamlar içerisinde yer alan ve son yıllarda yapılan bir rekonstrüksiyon çalışması ile ayağa kaldırılan Sultan Hamamı'nda ise, diğer mekânların özgün durumu hakkında kesin bir bilgi bulunmadığından, günümüze özgün örtü ve duvarları ulaşabilen sıcaklık mekânı ve halvet hücreleri inceleme kapsamına alınmıştır.

\section{Hamam Kültürü ve Mimarisi}

Kamusal kullanımın önemli alanlarından olan hamamlar, sadece y1kanma/temizlenme eyleminin gerçekleştirildiği yapılar olarak değil, aynı zamanda birer sosyalleşme mekânı olarak da her dönemde ön plana çıkmıştır. Dünya literatüründe Roma hamamlarından farklılaşan özellikleriyle "Türk Hamamı" olarak isimlendirilen yapılar, binyıllar boyunca yıkanma kültürünün farklı katmanlarından beslenen bir geleneğin devamı olmuş, yerleşimin nüfusu, dönemin mimari üslubu ve teknolojik imkânlar doğrultusunda şekillendirilerek Anadolu kent dokusu içerisinde mimari ve kültürel olarak daima özel bir önem taşımışlardır.

Volume 12

Issue 4

August

2020

Yıkanma ve vücut temizliği, insanlığın ilk dönemlerinden beri yaşam kültürünün bir parçasıdır. Bu eylem çoğu zaman sadece temizlikle ilgili olmamış, kutsal kabul edilen suyun kullanıldığ dini bir ritüele dönüşmüştür. İlk Çağ toplulukları, kutsal kabul ettikleri akarsu ve sıcak su kaynaklarında yıkanma eylemini ve aynı zamanda su ile ruh temizliğini gerçekleştirerek bunu dinsel bir törene dönüştürmüşler, özellikle Kafkasya ve Moğolistan'daki Neolitik Dönem toplulukları bu töreni mağara, çadır v.b. kapalı mekânlarda gerçekleştirmişlerdir. ${ }^{2}$ Mısır'da Nil, Mezopotamya'da Fırat, Hindistan'da Ganj nehirlerinin de bu amaca hizmet ettikleri düşünülmektedir. ${ }^{3}$ Son yüzyılda yapılan arkeolojik buluntular, bu durumun Anadolu için de geçerli olduğunu ortaya koymaktadır. ${ }^{4}$ Hititler doğal sıcak su kaynakları üzerine kurulan havuzlarda dinsel bir ayin şeklinde yıkanma eylemini gerçekleştirmişlerdir. ${ }^{5}$ Tilmen Höyük, Arslantaş, Zincirli, Can Hasan gibi arkeolojik alanlarda yapılan kazılar, bu dönemlerde yıkanma mekânlarının sadece kamusal alanlarda değil, yüksek sınıfa mensup ailelerin konutlarında da bulunduğunu göstermektedir. ${ }^{6}$ Eski Türk topluluklarındaki metinlerde kullanılan ve hamam terimine karşılık gelen "munça-munçak"

\footnotetext{
${ }^{2}$ Erika Brödner, "Zur Entwicklungsgeschichte Des Bades", Antike Welt, S. 8/4, 1977, s. 45-56.

${ }^{3}$ Karl Klinghardt, Türkische Bader, Mit 85 Abbildungen Und Einer Karte, J. Hoffman, Stutgart 1927, s. 9.

${ }^{4}$ Birsen Erat, Anadolu'da XIV. Yüzyll Türk Hamam Mimarisi, (Ankara Üniversitesi Sosyal Bilimler Enstitüsü, Yayımlanmamış Doktora Tezi), Ankara 1997, s. 21-29.

${ }^{5}$ Ekrem Akurgal- Max Hirmer Die Kunst Der Hethiter, Hirmer, München 1976, s.51.

${ }^{6}$ Erich Ebeling - Bruno Meissner, Reullexion Der Assyrioligie, W. De Gruyter\&Co., Berlin Und Leipzigg 1928, s. 388; Rudolf Naumann, Eski Anadolu Mimarlı̆̆l, Türk Tarih Kurumu Basımevi, Ankara 1991, s. 159.
} 
sözlerinden, Türklerin de yıkanmaya önem verdikleri ve bazı yerleşik alanlarda bu tür yapılara sahip oldukları anlaşılmaktadır. Göçebe Türkler ise bu amaçla "çerge" adı verilen çadır hamamlarını kullanmışlardır. ${ }^{7}$

Yıkanmak için yapılan ilk kapalı mekânların izlerine, Hindistan, Pakistan, Anadolu, Mezopotamya, Mısır, Antik Ege ve Yunan uygarlıklarındaki saraylarda rastlanmıştır. ${ }^{8}$ Çeşitli coğrafyalarda ve dönemlerde hamam kalıntıları bulunduğu kaydedilse de bugünkü hamamlara çok benzer işlevler gören, içi ısıtılan, sıcak su akan binalar yaygın olarak ilk kez M.Ö. 4. yüzyıl başlarında Atina'da kullanılmıştır'. Temizlenme eylemine önem verilen Klasik Yunan kültüründe, konut ve saraylarda yer alan mekânların yanı sıra yıkanma ve tedavi amacına hizmet eden kaplıcalar da inşa edilmiştir. ${ }^{10}$ Yine spor yapma amacıyla inşa edilen gymnasiumlarda da yıkanma mekânlarına yer verilmiştir. ${ }^{11}$ Sadece temizlik değil birer sağlık kurumu işlevi gören Yunan hamamları, imparatorluk dönemi Roma uygarlığında Ortaçağ başlarına kadar bu modeli geliştirerek kurumsallaşmışlardır. Mekân organizasyonu açısından birbirini bütünleyen değişik ünitelerin belirgin bir tipoloji oluşturdukları bu modeldeki üç temel öğe olan Frigidarium (soğukluk), Tepidarium (1lıklık) ve Caldarium (sıcaklık), bölgesel bazı değişiklikler göstermekle beraber Bizans ve Türk hamamlarında da yapının ana mekânları olmuşlardır. ${ }^{12}$

Etrüsk medeniyetinde kullanılan hamamların yanı sıra, zengin Romalılar, Yunan uygarlığından esinlenerek evlerine banyo odaları yapmışlardır. ${ }^{13}$ Klasik Yunan kentlerinde halka açık yıkanma mekânları bulunmakla birlikte mimari ve işlevsel olarak gelişmiş hamam yapılarına dair ilk somut izlere Roma Döneminde rastlanmaktadır. ${ }^{14}$ Bu yapılar temizliğin yanı sıra sosyal iletişim mekânları olarak da kullanılmışlardır. Zengin Romalıların villaları dışında konutlarda akan su ve banyo düzeneği bulunmadığından, hamamlar halk için önemli birer konfor alanı olmuş, aynı zamanda ekonomik olarak da kazançlı bir girişim olarak görülmüştür. Alt gelir grubunun bile dışarıda kalmayacağı şekilde oldukça düşük miktarda giriş ücretlerinin olmasına ragmen, sürekli kullanılmaları nedeniyle bu yapılar ciddi bir ekonomik gelir sağlamışlardır. ${ }^{15}$ Kökeni Yunan hamamları olan ancak hamam mimarisinin geliştiği ilk dönem olarak kabul edilen Roma döneminde de Yunan hamamlarına benzer şekilde, hamamlar, farklı işlevlere hizmet eden mekânları içermiştir. ${ }^{16}$

\footnotetext{
${ }^{7}$ Osman Turan, Selçuklular Tarihi ve Türk İslam Medeniyeti, Türk Kültürünü Araştırma Enstitüsü Yayınları, Ankara 1965, s. 254; Osman Turan, Selçuklular Zamanında Türkiye, Turan Neşriyat Yurdu, İstanbul 1971, s. 370; Bahaeddin Ögel, Türk Kültür Tarihine Giriş, C. 3, Kültür Bakanlı̆̆ 1 Yayınları, Ankara 197, s. 108)

8 Aru, Kemal Ahmet Aru, Türk Hamamlarl Etüdü, (İstanbul Teknik Üniversitesi Yayımlanmamış Doçentlik Tezi, İstanbul 1949, s. 11; Semavi Eyice, "Hamam". Türkiye Diyanet Vakfi İslam Ansiklopedisi., C. 15, Diyanet İşleri Başkanlığı Yayınları, İstanbul 1997, s. 402.

${ }^{9}$ Haluk Abbasoğlu, Pamphylia Bölgesi Roma Devri Hamamları, (İstanbul Üniversitesi Yayımlanmamış Doçentlik Tezi), İstanbul 1982, s. 751.

${ }^{10}$ Ekrem Akurgal, Ancient Civilizations And Ruins Of Turkey, Haset Kitabevi, İstanbul 1973, s. 47.

${ }^{11}$ Klinghardt, age, s. 12.

12 Tevfik Cem Yaman, Türk Hamamının Mekânsal Kurgusu, Istanbul Hamamlarl, (Mimar Sinan Güzel Sanatlar Üniversitesi Yayımlanmamış Yüksek Lisans Tezi), İstanbul 2010, s. 5.

${ }_{13}$ Abbasoğlu, agt, s. 751 .

${ }^{14}$, Somay Onurkan, “Anadolu'da Eski Yunan ve Roma Arkeolojisi”, Anadolu Uygarlıkları, Görsel Anadolu Tarihi Ansiklopedisi, C. 3, Görsel Yayınlar, İstanbul 1985, s. 450-474.

${ }^{15}$ Fikret Yegül, Roma Dünyasında Yıkanma, Koç Üniversitesi Yayınları, İstanbul 2010, s. 29.

${ }^{16}$ Behçet Ünsal, Mimari Tarihi, C. 1, İ.T.O. Yayınları, Marifet Matbaası, İstanbul 1960, s. 478.
} 
Romalıların geliştirdiği, şehir merkezlerine suyun ulaştırılmasını sağlayan su kemerleri ve kanalizasyon sisteminin de hamamların mimari gelişiminde etkili olduğu düşünülmektedir. Ayrıca bu dönemde icat edilen ve hypocaust adı verilen döşeme altı 1sıtma sistemleri, mekansal ihtiyaçlara göre 1sının farklı derecelerde uygulanmasına imkan vermis, bu teknolojik gelişme Roma hamamlarının kurgusunda önemli rol oynamıştır. Roma döneminde hamamların gece kullanımı, çok özel durumlar haricinde enderdir. Müşteriler bol gün 1şığında yıkanmayı tercih etmiş, büyük pencerelere sahip olan, iyi aydınlatılan hamamlara özel ilgi göstermişlerdir. ${ }^{17}$ Bizans döneminde de Roma hamam geleneği sürdürülmüss, Roma'da olduğu gibi hamamlar yıkanma eyleminin dışında, eğlencelerin düzenlendiği, siyasi tartışmaların yapıldı̆̆ı birer sosyal aktivite alanı olarak kullanılmıştır. ${ }^{18}$

Aynı dönemlerde İslam coğrafyasında da kullanılmaya başlayan hamamlar, mekânsal olarak kısmi farklılıklar gösterse de işlev açısından aynı geleneği sürdürmüşlerdir. ${ }^{19}$ Anadolu'ya gelmeden önce Türklerin han, saray, köşk v.b. yapılarda özel yıkanma mekânlarının bulunduğu, ayrıca halka açık yapıların varlığı yazılı kaynaklarda yer almaktadır. ${ }^{20}$ Bizans'a yakın bir bölgede bulunan Emevi Dönemi ilk İslam hamamlarında ve Memluk hamamlarında da mekân düzenleri, mimari özellikleri ve 1sitma sistemleri ile Roma hamam mimarisi etkisi altında şekillenmekle birlikte İslam dininin temizlik kurallarına uygun olarak yıkanmayı sağlayabilmek için, sıcak ve soğuk su havuzlarının yerine, akan su sistemi kullanılmıştır. Mimari düzen ise Roma-Bizans geleneği ile hemen hemen aynı şekilde devam ettirilmiştir. ${ }^{21}$ Orta Asya bölgesinde ise Kirman Nigar Hamamı ve Kirgizistan'da bir saray kompleksine ait hamam dışında günümüze ulaşan bir yapı bulunmamaktadır. ${ }^{22}$ Büyük Selçuklular Döneminde inşa edilen Kirman-Nigar Hamamı'nın, 10. yüzyıl Orta Asya sivil mimarisine bağlanan bir geleneğin devamı niteliğinde sıcaklık bölümünde uygulanan 4 eyvanlı plan şeması ile, yakın dönemlerde Anadolu'da ortaya çıkan Türk hamam mimarisinin ana şemasını oluşturduğu düşünülmektedir. ${ }^{23} \mathrm{Bu}$ mimari kompozisyonda Roma hamamlarının yanı sıra, ilk kaplıca örneklerinin de etkili olduğu düşünülmektedir. Birisi her türlü hava şartlarında soyunup giyinmeyi, diğeri sıcak sulu havuzda yıkanmayı sağlamak amacıyla yan yana iki hacimden yapılmış bu yapı türleri, hamamların sağlık işlevini de ön plana çıkarmış, 12.-13. yüzyıl Türk hamamlarında kurnalara sadece sıcak su akıtılmıştır. ${ }^{24}$

$\mathrm{Su}$ ve 1sıtma tesisatı bakımından erken dönem örneklerinden faydalanan, ancak havuz yerine akan su ile temizlik yapılan Anadolu Türk hamamlarının temel mekân kurgusu, aksiyel eyvanlı, köşe halvetli, merkezi mekân şeması üzerinden geliştirilmiştir. ${ }^{25}$ Özellikle Selçuklu döneminden itibaren haçvari sıcaklık şeması daha çok uygulanmaya başlamıştır. Tek olarak

\footnotetext{
17 Yegül, agt, s. 29, 105.

18 Nezih Başgelen, v.d. "Bizans İstanbul'u”, İstanbul'un Dört Çă̆l, Ed. Fatma Türe, Yap1 Kredi Yayınları, İstanbul 1999, s. 24-25; Alidost Ertuğrul, "Hamam Yapıları ve Literatürü”, Türkiye Araştırmaları Literatür Dergisi, S. 7/13, 2009, s. 241-266.

${ }^{19}$ Aru, age, s. 14.

${ }^{20}$ Turan, 1965, age, s. 254.

21 Felix Genzmer, Anlage Und Einrichtung Der Gedaude - Bade Und Schwimmanftalten, J.M. Gebhardt's Verlag, Leipzig 1921, s. 22.

${ }^{22}$ Erat, agt, s. 27.

${ }^{23}$ Hilmi Ziya Ülken, İslam Sanatı, İstanbul Teknik Üniversitesi Matbaası, İstanbul 1948, s. 355.

24, Yılmaz Önge, “Anadolu'da XII-XIII. Yüzyıl Hamamları Hakkında Genel Bilgiler ve Mimar Koca Sinan’ın İnşa Ettiği Hamamlar”, Mimarbaşı Koca Sinan, Yaşadı̆̆ı Çağ ve Eserleri, C. 1, Ed. Sadi Bayram, T.C Başbakanlık Vakıflar Genel Müdürlüğü Yayınları, İstanbul 1988, s. 404-415

${ }^{25}$ Yılmaz Önge, Anadolu'da XII. ve XIII. Türk Hamamlarl, Vakıflar Genel Müdürlüğü Yayınları, Ankara 1995, s. 9.
} 
inşa edilen hamamların yanı sıra erkek ve kadınlar için bitişik iki bina şeklinde inşa edilen çifte hamamlar da mevcuttur. Külliyeler içerisinde yer alan hamamların yanı sıra Kırşehir Karakurt Han Ilıcası gibi 1lıca/kaplıca ve han birlikteliği gibi farklı örnekler de bulunmaktadır. ${ }^{26}$ Selçuklu döneminin çifte hamamlarının plan şeması, aradaki aks boyunca ve her iki kısımda sıralanan soyunmalık, aralık, soğukluk, sıcaklık, su deposu ve külhandan oluşmaktadır. ${ }^{27}$ Bu hamamların plan düzeninin Beylikler Döneminde de tekrarlandığ görülmektedir. ${ }^{28}$

Osmanlı Döneminde yalı ve konaklar dışında çoğu eve su verilmemesi nedeniyle bu evlerde yaşayan halk yıkanma ihtiyaçlarını halk hamamı denilen yapılarda sağlamışlardır. Saraylarda ise hükümdar ve ailesi için saray hamamları inşa edilmiştir. Ayrıca şifalı sıcak kaynak suyunun çıktığı yerlerde de kaplıcalar yapılmıştır. ${ }^{29}$ Hamamlar tarihsel süreçte dini ve ticari yapılarla birlikte şehir hayatının önemli yapıları haline gelmiş ve genellikle külliye şeklinde; dini, kültürel ve sosyal yapılarla ilişkilendirilmişlerdir. Başta İstanbul olmak üzere Anadolu şehirlerindeki yoğun inşa faaliyeti ve bu işleyişin imaret sistemi çerçevesinde şekillenmesi, bu yapıların kentle organik bir ilişki kurmasına sebep olmuştur. Toplumsal gelenekler göz önünde bulundurularak çalışanların sağlık ve temizliği için, özellikle külliye inşaatları esnasında hamam inşasına öncelik tanınmıştır. Yine imarete sağlanan gelirler açısından bu yapıların en az çarşılar kadar kazanç sağlaması da hamam inşasının temel nedenlerinden birisi olmuştur. ${ }^{30}$ Diğer bir gerekçe ise hamamların ait oldukları yapı topluluğunun merkezi olan cami cemaatine hizmet vermesidir. ${ }^{31}$

Osmanlı Dönemi hamam mimarisi, Anadolu'nun çok kültürlü yapısının bir parçası olarak, barındırdığı geçmiş kültürlerin ve temas ettiği komşu coğrafyaların etkisi altında şekillenmiştir. $\mathrm{Bu}$ kapsamda dini ve kültürel olarak farklı bir medeniyetin ürünü olan Roma hamamlarının plan kurgusu temel alınmış, mekân kullanımı yeniden düzenlenmiştir. Bu düzenleme esnasında özellikle sıcaklık bölümlerinde farklı denemeler yapılmış, bazı yapılarda Roma-Bizans hamamlarındaki yıldız şema kullanılmış, bazı yapılarda ise Selçuklu yapılarındaki haçvari, dört eyvanlı şema tercih edilmiş, farklı dönemler ve bölgelere göre bu şemalar geliştirilerek çeşitlendirilmiştir ${ }^{32}$. Nüfus artışı ve teknolojik gelişmeler hamam mimarisine de yansımış, 14. yüzyıldan sonra soyunmalık mekânları büyük bir kubbe ile örtülmeye başlamıştır. Erken dönem Osmanlı hamamları bu kubbelerin zengin süslemesi ile özellik kazanmıştır. ${ }^{33}$ Soyunmalığın duvarlarına, alttakiler dikdörtgen, üsttekiler kemerli olmak üzere iki veya üç sıra pencere açılması ise 16. yüzyıl hamamı özelliklerindendir. Erken dönem hamamlarının boyutları küçük, planları asimetrik iken, klasik dönemde tamamen simetrik ve çifte hamamlar yoğunluk kazanır. 17.-18. yüzyılların hamam mimarisinde, kubbeli bir merkezi mekâna göre aksiyel eyvanlı ve köşe halvetli haçvari sıcaklık şemasının uygulanmıştır. ${ }^{34}$ Genel olarak Osmanlı Dönemi hamamlarının plan şemaları incelendiğinde; haçvari dört eyvanlı ve köşe hücreli tip, yıldızvari sıcaklıklı tip, kare bir sıcaklık etrafında sıralanan halvet hücreli tip, çok kubbeli sıcaklıklı tip,

\footnotetext{
26 İbrahim Yılmaz, “Kırşehir'de Selçuklu Dönemine Ait Bir Yapı Karakurt Han-Ilıcası”, Uluslararası Hakemli Tasartm ve Mimarlı Dergisi, S.10, 2017, s. 56-79.

27 Önge 1988, age, s. 409.

28 Süheyla Atlı, Mimar Sinan Dönemi Hamamları Konusunda Bir Araştırma, (Mimar Sinan Güzel Sanatlar Üniversitesi Fen Bilimleri Enstitüsü, Yayımlanmamış Yüksek Lisans Tezi), İstanbul 1990, s. 16.

${ }^{29}$ Elif Şehitoğlu, Bursa Hamamları, Tarih Vakfı Yurt Yayınları, İstanbul 2006, s. 9.

${ }^{30}$ Yaman, agt, s. 6.

${ }^{31}$ Eyice, age, s. 402-430.

${ }^{32}$ Genzmer, age, s. 22.

${ }^{33}$ Doğan Kuban, 100 Soruda Türkiye Sanat Tarihi, Gerçek Yayınevi, İstanbul 1981, s. 198.

34 Önge 1988, age, 409-410.
} 
ortası kubbeli, enine sıcaklıklı ve çift halvetli tip ve soğukluk, sıcaklık ve halvetin eş odalar halinde olduğu tip olmak üzere 6 plan şemasının bulunduğu görülmektedir. ${ }^{35}$

Yalın ve fonksiyonel bir iç mekân şemasına sahip olan Türk hamamlarındaki mekânlar, soyunmalık, 1lıklık (soğukluk), sıcaklık ve külhan olmak üzere 4 ana başlıkta toplanmaktadır. Camekân (camegah) olarak da adlandırılan soyunmalık, hamamın giriş bölümüdür. Cümle kapısından girilen, soyunma ve kabul işlemlerinin yapıldığı mekân olan soyunmalık, genellikle kare veya kareye yakın dikdörtgen plan şemasına sahiptir. ${ }^{36}$ Soyunmalığın 1sıtma sistemi ve sıcak su tesisatı yoktur. Isıtma kış aylarında mangallar aracılığıyla sağlanır. Duvarlarda açılan pencereler, içeriden dışarısı, dışarıdan da içerisi görülmeyecek yüksekliktedir. İki sıra pencerenin olduğu durumlarda, üst sıradakiler renkli alçı pencere olur ve mekâna renk katar. ${ }^{37}$ Soyunmalıktan 1lıklı̆ga, aralık da denilen, üzerinde külah şeklinde bir baca olan mekândan geçilir. Bu bacanın amacı, sıcak olan iç hacimden çıkacak buharı buğu yapmadan çekip dışarı atmaktır. Soğukluk, ılıklık veya kapıarası olarak isimlendirilen mekân, sıcaklığa geçmeden önce vücudu ısıya alıştırmak veya sıcaklıktan çıkıp ferahlamak için kullanılır. Çok soğuk dönemlerde soyunma eylemi de bu mekânda yapılabilir. Tuvaletler ve diğer küçük mekânlar genellikle bu alana açılan daha alçak bölmelerdir. Sıcaklık, yıkanma eyleminin gerçekleştirildiği, ortasında çoğunlukla göbek taşı bulunan merkezi bir mekân etrafında düzenlenmiş bir alandır. Bu merkezi mekânın köşelerinde 'halvet' adı verilen, ana mekândan daha sıcak tekil yıkanma hücreleri bulunur. Bu hücreler arasında kalan ve 'eyvan' olarak adlandırılan nişler, genel yıkanma alanlarıdır. ${ }^{38}$ Hamamın tesisat merkezi külhan, olarak adlandırılır. Girişi ayrı bir mekân olan külhanın yanında bir sıcak su deposu bulunur. Depodaki suyu ısıtma amacıyla ocak yakılan külhanın zemin kotu, genellikle su deposunun hizasındadır. Ocağın dumanları cehennemlik adı verilen ve döşeme altında dolaşan kanallarda dolaşarak hamamı 1sıtır. Duman duvar içine yerleştirilmiş tüteklik denilen toprak borulardan geçerek dışarı atılırken aynı zamanda duvarların da 1sınmasına yardımcı olur. ${ }^{39}$

\section{Türk Hamamında Aydınlatma Elemanları}

Gün ışığından yararlanmak amacıyla yapı elemanlarında bırakılan açıklıklar, doğal aydınlatma sistemine ait elemanlar olarak tanımlanmaktadır. Günümüz yapılarında pencereler, kapılar, çatı 1şıklıkları gibi elemanlardan oluşan doğal aydınlatma sistemi, Türk hamam mimarisinde, 1şık/aydınlık fenerleri, aydınlık pencereleri, 1şık gözü/fil gözü ve 1şı tavanları olarak karşımıza çıkmaktadır. Bu açıklıkların yanı sıra bazı mekânlarda kandiller, şamdanlar v.b. yapma aydınlatma elemanlarının da kullanıldığı bilinmektedir.

\subsection{Işıı/aydınlık fenerleri}

Hamamlardaki mahremiyet gereksinimi nedeniyle doğal aydınlatma genellikle tavan örtülerine açılan açıklıklar ile sağlanır. Hamam yapılarındaki doğal aydınlatmada kullanılan önemli yapı elemanlarından biri aydınlık fenerleridir. Tavan örtüsünde yer alan bu fenerlerden

\footnotetext{
${ }^{35}$ Semavi Eyice, “İznik’te Büyük Hamam ve Osmanlı Devri Hamamları”, Tarih Dergisi, S. XI, 1960, s. 99-120.

${ }^{36}$ Ayla Ödekan, "Hamam”, Eczacıbaşı Sanat Ansiklopedisi, C. 2, YEM Yayınları, İstanbul 1998, s. 750753.

37 Tülay Taşçığlu, Türk Hamamı, TTOK Yayınları, İstanbul 1998, s. 37.

38 Önge 1988, age, s. 408.

${ }^{39}$ Aru, agt, s. 10.
} 
günümüze genellikle taş malzeme ile inşa edilenleri ulaşabilmiştir. Ahşap malzemeli en eski örnekleri ile ilgili detaylı bilgilere ulaşılamamakta olup soyunmalıklarda merkezdeki şadırvanın üzerine denk gelen tavan ile birlikte yok olduğu ya da onarımlar sırasında özgünlügünü kaybettiği varsayılmaktadır. ${ }^{40}$

Işık fenerlerinin yapım sistemi, tavan üst örtüsüne göre şekillenmiştir. Ahşap çatılı yapılarda 1şık fenerinde de ahşap kullanılırken, kâgir kubbeler üzerinde yükselen 1şık fenerlerinde taş malzeme tercih edilmiştir. Ahşap 1şık fenerlerinde, yapının üst örtü kurgusuna bağlı olarak genellikle iki farklı yöntem uygulanmıştır. İki yöntemde de fener üst örtünün merkezinde, genellikle şadırvana denk gelen kısımda yer alır. İlk yöntemde fenerin prizmatik gövdesi, tavandaki bir kaide üzerinde çatı yüzeyinden yükseltilmiştir. İkinci yöntemde ise fener, ahşap tavan üzerinde dışarı taşıp kare veya sekizgen taban üzerinde merkeze doğru daraltılmıştır. En eski örneğine 15. yüzyılda rastlanan taş 1şı fenerlerinde yapım sistemi farklılaşmış, özellikle 16. yüzyılda kare, altıgen, sekizgen veya onikigen prizma biçimindeki fenerlerin gövdeleri, köşelerde yer alan taş ayaklara veya küçük sütunlara kemerlerle ya da lentolara oturtulmuş ve küçük kubbeler ile örtülmüşlerdir. İstanbul Çemberlitaş Hamamı'nda sekiz sütunun taşıdığı sivri kemerlere oturtulmuş, eteği taçlı kubbe ile örtülmüş 1şık fenerleri mevcuttur. $\mathrm{Bu}$ tip sütunlu fenerlerde prizmatik gövdenin pencerelerine yerleştirilmiş camlı doğramalar yerine, fener kaidesindeki 1 şı açıklığını örten, daha alçak tutulmuş prizmatik veya konik bir cam kapak kullanılmıştır. ${ }^{41}$ Anadolu'daki hamamların da birçoğunda, özellikle soyunmalık bölümlerinde aydınlık fenerleri sıklıkla gözlemlenebilmektedir. Konya Hasbeyoğlu Hamamı, Trabzon İskender Paşa Hamamı, Bursa Muradiye Hamamı soyunmalık mekânları aydınlık fenerleri ile aydınlatılan önemli örneklerdir. ${ }^{42}$

\subsection{Aydınlık pencereleri}

Duvarlara, üst örtüye veya tonoz sırtlarına açlan, genellikle kare, dikdörtgen veya dairesel forma sahip pencerelerdir. Aydınlık pencerelerine; Beylikler Dönemiyle birlikte büyük hamamlarda soyunmalıklar kubbe ile örtülmeye başladıktan sonra rastlanmaktadır. İlk uygulamalarında soyunmalık duvarlarına iki sıra pencereler halinde uygulanıp daha sonra kubbeye de küçük pencereler eklenmiştir Aydınlık pencerelerinin en önemli kullanımı; Mimar Sinan'ın eseri Ayasofya-Haseki Hürrem Sultan Hamamı'nda görülmektedir. Yapı; 1şık fenerlerinin yanı sıra cephelere veya tavana açılan aydınlık pencerelerinin de kullanımıyla, hacimde doğal 1şı̆̆ en iyi alabilen Osmanlı hamamı olarak tanımlanmaktadır. ${ }^{43} 15$. yüzyıldan sonra soyunmalıklara daha fazla 1şık sağlamak amacıyla, zemin seviyesine yakın demir parmaklıklı ve ahşap kafesli alt pencereler ile birlikte, kubbe etek seviyesine yakın, renkli camll, alçı üst pencereler kullanılmıştır. ${ }^{44}$.

\subsection{Işı gözü-fil gözü}

Türk hamamlarında doğal aydınlatmanın sağlanmasında, soyunma mekânlarındaki aydınlık fenerlerinden sonra en çok dikkati çeken mimari detaylara sıcaklık mekânlarında rastlanır. Işık gözleri, özellikle hamamlarda birçok mekânda kullanımı tercih edilen özel pencerelerdir. 12.-

\footnotetext{
${ }^{40}$ Yılmaz Önge, "Eski Türk Hamamlarında Aydınlatma”, Vakıflar Dergisi, S. 12, 1979, s. 121-137.

${ }^{41}$ Önge 1979, age, s. 122-124.

42 Arife Deniz Oktaç, Anadolu Türk Mimarisinde Aydınlatma Detayları ve Aydınlatma Elemanları, (Selçuk Üniversitesi Fen Bilimleri Enstitüsü, Yayımlanmamış Yüksek Lisans Tezi), Konya 1992, s. 18; Funda Kurak Açıcı, "Trabzon Türk Devri Yapısı İskender Paşa Cami ve Külliyesi”, Uluslararası Hakemli Tasarım ve Mimarlık Dergisi, S. 10, 2017, s. 275-289.

43 Önge 1988, age, s. 415.

44 Önge 1979, age, s. 128.
} 
13. yüzyıla ait örneklerde merkezi sıcaklık kubbesinin ortasında bir 1şık kubbeciğinin bulunduğu, 13. yüzyıldan itibaren bunun çevresinde ayrı ayrı veya birleşik 1şık gözlerinden oluşan 1şıklık çemberlerinin oluşturulduğu görülmektedir. 15. yüzyıla kadar bazı örneklerde tek bir ışık gözü bulunan eyvanlar ve bağımsız olarak aydınlatılmış halvetler dışında, merkezi mekânın kubbesi, sıcaklık bölümünün doğal aydınlatma sağlanan önemli bir bölümü olmuştur. Halvetlerin kubbelerinde ise yine erken dönem hamamlarında sadece bir 1şık açıklı̆̆ bulunmaktadır. 13. yüzyıl Kayseri Hunat Hamamı ve 14. yüzyıl Konya Seydiler (Seyyid Harun Veli) Hamamı'nda halvet kubbelerinin toprak altında kaldığı, 1şık açıklığını kurtaracak yükseklikte taş veya tuğladan bir yaka ile çevrilerek üzerine cam kapaklar konulduğu anlaşılmaktadır. ${ }^{45}$

\subsection{Işı tavanları}

15. yüzyıldan itibaren hamam yapılarında farklı doğal aydınlatma detaylarına da rastlanmaktadır. Işık tavanları genelde küçük tonoz veya kubbe aynalarına yerleştirilmiş, kafes görünüşündeki örtülerdir. Tonoz veya kubbelerin etek seviyesinde bulunan 1şık tavanları, üzerine geometrik şekiller oyulmuş taş levhalardan veya sıvalardan yapılmıştır. Işık tavanlarının bir diğer farklı uygulaması ise hamamların merkezi sıcaklık kubbelerinde kullanılan, basık küre kapağı biçimindeki çok gözlü 1şık tavanlarıdır. Bu tip 1şık tavanları, kubbenin inşası esnasında tepede bırakılan geniş açılığın, içine toprak künkler yerleştirilen dairesel bir örtüyle kapatılması sonucunda meydana gelmişlerdir Bu ışı tavanlarına daha çok Güneydoğu Anadolu bölgesindeki hamamlarda rastlanmaktadır. ${ }^{46}$

18. ve 19. yüzyılda özellikle İstanbul'da yapılan saray ve köşk hamamlarında, soğukluk ve sıcaklık mekânlarının örtülerinde, yarım küre şeklindeki klasik kubbelerin yerine basık kubbe veya tonozlar tercih edilmiş, bu örtüler çok sayıda 1şık gözüyle adeta şeffaflaştırılmıştır. 19. yy. ortalarında yapılan Dolmabahçe Sarayı Hünkâr Hamamı'nın madeni karkas bir sistemin taşıdığı camekânlı tavan örtüsü, en karakteristik örneklerdendir. ${ }^{47}$

\subsection{Yapma aydınlatma elemanları}

Yapılarda doğal aydınlatmanın yeterli gelmediği veya doğal aydınlatma istenmediği durumlarda kullanılan aydınlatma sistemi, yapma aydınlatma olarak tanımlanır. 15. yüzyıla kadar yapma aydınlatma sistemine ilişkin bir bilgiye rastlanmamaktadır. 15. ve 16. yüzyıllarda ise saray hamamları ve özel hamamlarda hizmetlilerin taşıdığı büyük şamdanlar, duvarlara çivilerle asılmış kandiller ve fenerlerin kullanıldığını gösteren minyatürler bulunmaktadır. Bu kullanımın halk hamamlarında da aynı şekilde olduğu düşünülmektedir. Fenerler ve kandiller ile aydınlatma sağlanması için beziryağı, gazyağı, zeytinyağı, haşhaş yağı gibi yağlar kullanılmıştır. 15. yüzyıldan sonra inşa edilen özel ve genel hamamlardaki küçük nişlerin, kandil, şamdan vb. ekipmanların yerleştirilmesi için tasarlandığı düşünülmektedir. ${ }^{48} \mathrm{Bu}$ uygulamaların en önemli örneklerine Mimar Sinan'ın 16. yüzyılda yaptı̆̆ı Ayasofya Hamamı erkekler kısmındaki soğukluk ve sıcaklık mekânlarında rastlanmaktadır. Yapıda duvarların üzerine sıvadan yapılmış konsol rafları, şamdan, kandil, fener gibi yapma aydınlatma araçlarını yerleştirmek için "çırağman" denilen küçük nişler mevcuttur. ${ }^{49}$ Dolmabahçe Sarayı Çinili Hamamın soğukluk mekânında bulunan Kütahya çinili masanın üzerine yerleştirilen sekiz adet mumluk, yapma aydınlatma elemanı olarak kullanılmıştır. Yine Dolmabahçe Sarayı

${ }^{45}$ Age, s. 126-130; Yaman, agt, s. 218.

${ }^{46}$ Age, s. 130-131.

${ }^{47}$ Age, s. 131-132.

${ }^{48}$ Mahmut Akok, “Çorum'da Ali Paşa Hamamı”, Arkitekt, S. 280, 1955, s. 85-91.

${ }^{49}$ Eyice 1997, age, s. 417. 
hamamlarında, yapma aydınlatma için duvar yüzeylerinde her iki taraftan kullanılmak üzere kapaklı nişler yapılmıştır. Ayrıca; saray içindeki hamamlarda tavandan sarkıt şeklinde kullanılan şamdanlar dikkati çekmekte olup 20. yüzyıldan itibaren elektrik tüketiminin hamamlarda da başlaması ile birlikte, hamamların büyüklügüne ya da kullanım şekline ve döneme göre değişen yapma 1şık kaynakları kullanılmaya başlanmıştır. ${ }^{50}$

\section{Kayseri Hamamlarında Aydınlatma Elemanları}

Kayseri'de hamamlar üzerine yapılan araştırmalar sonucu, kent merkezinde Selçuklu, Beylikler ve Osmanlı Dönemine ait 20 adet hamam olduğu görülmektedir. Arşiv belgelerinde ismi geçen ancak günümüze ulaşamayan 10 adet hamam daha bulunmaktadır. ${ }^{51} \mathrm{Bu}$ hamamlardan 9 adedi kent merkezinde konumlanmış olup Birlik Hamamı 1996 yılında tamamen yıkılmış, Gülük Hamamı'nın ise sadece temelleri ve duvarlarının bir kısmı günümüze ulaşabilmiştir. Çalışma kapsamında, Sultan Hamamı, Hunat Hamamı, Selahaddin Hamamı, Kadı Hamamı, Cafer Bey Hamamı, Deveci Hamamı ve Setenönü Hamamı ele alınarak doğal aydınlatma elemanlarının mekânlara göre kullanım çeşitliliği incelenmiştir.

\subsection{Sultan Hamamı}

13. yüzyılın başlarına tarihlendirilen yapı, Cumhuriyet Mahallesi, Sultanhamamı Sokağında bulunmaktadır. Orijinalinde çifte hamam olarak inşa edilen hamamın kadınlar bölümü tamamen yıkılmıştır. ${ }^{52}$ Günümüzde rekonstrüksiyon çalışmaları ile ayağa kaldırılan yapı, restoran olarak kullanılmaktadır. Onarımdan önce sadece sıcaklık bölümü ve halvet hücreleri ayakta olan yapının sıcaklık bölümü, kubbedeki aydınlık penceresi ve basık tonozun sırtına açılan 1şık gözleri ile aydınlatılmaktadır. Kubbeler ile örtülen halvet hücrelerinin ise 80-120 $\mathrm{cm}$. arasında değişen boyutlarda tavana açılan dairesel aydınlık pencereleri mevcuttur. Hamamın diğer bölümleri yıkıldığı için, bu bölümlerdeki orijinal aydınlatma elemanları hakkında bir iz bulunmamaktadır.

\subsection{Hunat (Huand Hatun) Hamamı}

Çifte hamam olarak kurgulanan ve 13. yüzyıla tarihlendirilen yap1, cami, medrese, türbe ve hamamdan oluşan bir külliye içerisinde yer almaktadır. Günümüzde hala hamam olarak kullanılan yapının erkekler bölümü incelendiğinde, üst örtüsü sonradan betonarme düz teras çatı ile örtülen ve orijinal mekân boyutunda olmadığı düşünülen ${ }^{53}$ soyunmalık bölümünün, bu örtü üzerine açılan dikdörtgen tepe pencereleri ve kuzey cephede yer alan 4 adet aydınlık penceresi ile 1şık aldığı görülmektedir. Soğukluğun aydınlatılması ise tonozun üzerindeki 3 adet 1şık gözü ile sağlanmıştır. Bu 1şık gözlerinden ortadaki kare, kenardakiler dairesel formdadır. Aralık ve tuvalet bölümlerinde, kubbeler üzerine açılmış aydınlık pencereleri kullanılmakta olup sıcaklık bölümünün aydınlatılmasında ise ortadaki ana mekânın kubbesindeki aydınlık feneri göze çarpmaktadır. Aydınlık fenerinin etrafına simetrik olarak yerleştirilen 16 adet $1 s ̧ ı k$ gözü bulunmaktadır. Sıcaklık eyvanları, tonozların sırtına açılan ışık gözleri ile aydınlatılırken halvet hücrelerinde kubbe üzerine açılan aydınlık pencerelerinin tercih edildiği görülmektedir (Fotoğraf 1, 2, 3).

\footnotetext{
${ }^{50}$ Yaman, agt, s. 231.

${ }^{51}$ Mustafa Denktaş, Kayseri'deki Tarihi Su Yapıları (Çeşmeler, Hamamlar), Kıvılcım Yayınları, Kayseri 2000, s. 274.

52 Osman Eravşar, "Sultan Hamamı”, Selçuklu Gevher Nesibe Sultan Tıp Fakültesi Sempozyumu, Erciyes Üniversitesi Matbaas1, Kayseri 1992, s. 32-35.

53, Erol Yurdakul, "Son Buluntulara Göre Kayseri'de Hunat Hamamı”, Selçuklu Araştırmaları Dergisi, S. II, 1971, s. 141-151.
} 


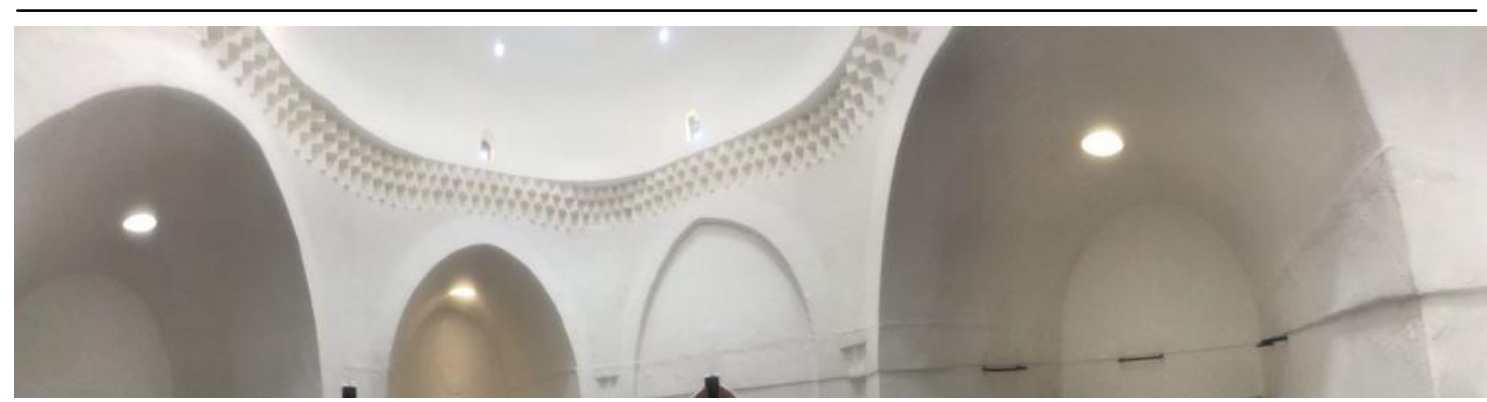

Fotoğraf 1. Hunat Hamamı sıcaklık eyvan kubbelerinde aydınlık pencereleri

Kadınlar bölümü soyunmalık mekânında, tonoz üst örtünün sırtına açılan, kare formlu 2 aydınlık penceresi ve iki cephenin üst kotlarına açılan aydınlık pencereleri mevcuttur. Aralık mekânı ve iki bölümlü soğuklukta, kubbelerin tepesine açılan birer aydınlık penceresi yer alır. Sıcaklığın merkezi kubbesinin ortasına açılan dairesel formlu aydınlık penceresi etrafındaki ışık gözleri ve tonoz sırtlarındaki aydınlık pencereleri ile ana mekânın 1şı alması sağlanırken halvet hücrelerinde yine erkekler bölümünde olduğu gibi kubbe üzerine açılan dairesel formlu aydınlık pencereleri ile mekânlara 1şık alındığı gözlemlenmektedir (Fotoğraf 3).
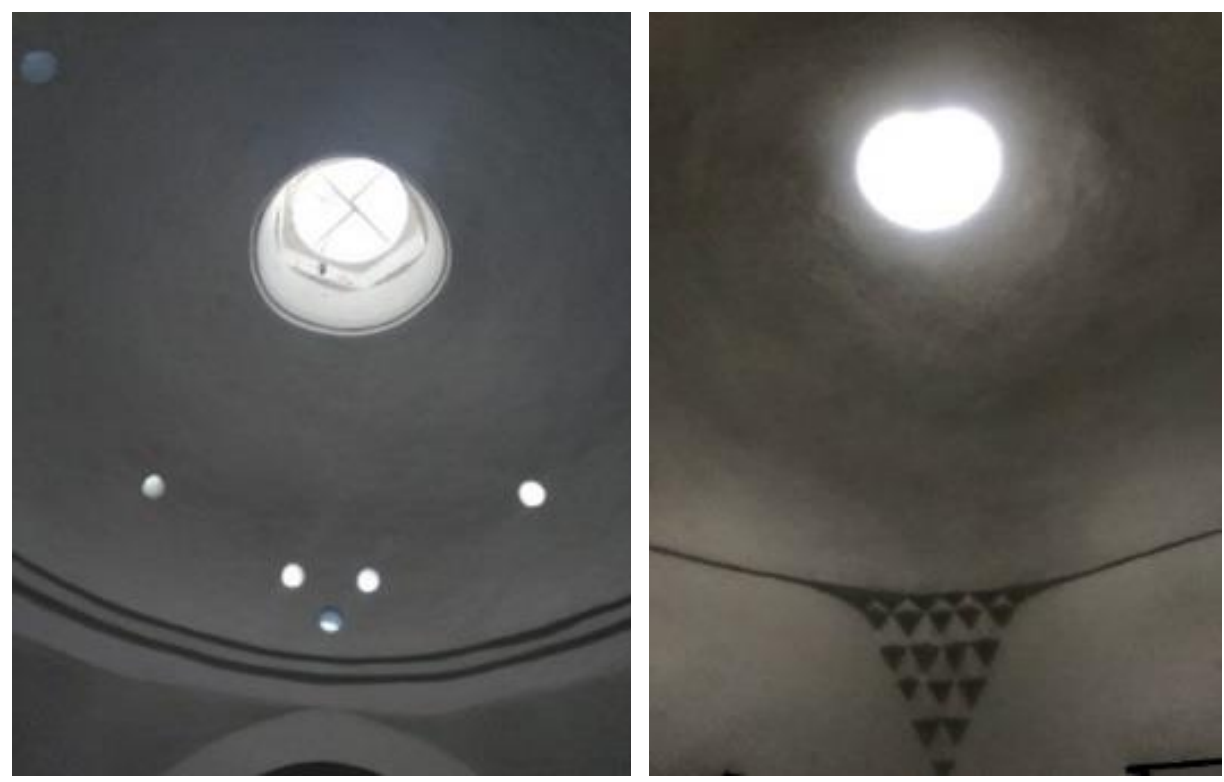

Fotoğraf 2, 3. Hunat Hamamı'nda aydınlık feneri ve pencerelerinin kullanımı

\subsection{Selahaddin Hamamı}

Çifte hamam olarak kurgulanan ve 14 . yüzyıla tarihlendirilen ${ }^{54}$ yapı, günümüzde hala hamam olarak kullanılmaktadır. Erkekler bölümü soyunmalık mekânı; kuzey ve güney duvarlarıa açılan ancak güneydeki sonradan kapatılan iki aydınlık penceresi, doğu duvarındaki 1 adet eğimli dikdörtgen aydınlık penceresi, tonozların sırtlarına açılan kare aydınlık pencereleri ve kubbedeki ışı gözleri ile aydınlatılmaktadır. Batıdaki kubbede 1, doğudaki kubbede 9, ortadaki kubbede 21 adet olmak üzere toplam 31 adet 1şık gözü bulunmaktadır. Sıcaklığın aydınlatılmasında ise kubbe ve tonozlar üzerine yerleştirilen 1 şı gözleri

54 Yıldıray Özbek ve Celil Arslan, Kayseri Taşınmaz Kültür Varlıkları Envanteri, C. II, Kayseri Büyükşehir Belediyesi Yayınları, Kayseri, 2008, s. 495. 
kullanılmıştır (Fotoğraf 4). Merkezi kubbe üzerinde 25, doğu, batı ve kuzey eyvanlarındaki tonozlar üzerinde dörder adet dairesel formlu ışık gözü yer alırken, güney eyvanı tonozundaki 2 adet 1şık gözünün dikdörtgen formlu olduğu görülmektedir. Güneydoğuda yer alan ve diğerlerine göre daha büyük olan halvet hücresi, iki kubbenin üzerine yerleştirilen birer aydınlık penceresi ile, diğer halvet hücreleri ise 1şık gözleri ile aydınlatılmaktadır. Kadınlar bölümü soyunmalığı, sonradan betonarme örtü ile kaplanmıştır. Soğukluk ve aralık mekânlarında, tonozlar üzerine açılan üçer adet kare formlu 1 şık gözü bulunmaktadır. Sıcaklığın giriş eyvanının tonoz sırtında kullanılan 7 adet kare formlu ışı gözü, ortadaki kubbeye ve yan eyvanların tonoz sırtlarına açılan kare aydınlık pencereleriyle sıcaklık mekânı aydınlatılmaktadır. Halvet hücrelerinde de yine tonoz sırtlarına açılan 1şık gözlerinin kullanıldığ 1 görülmektedir.
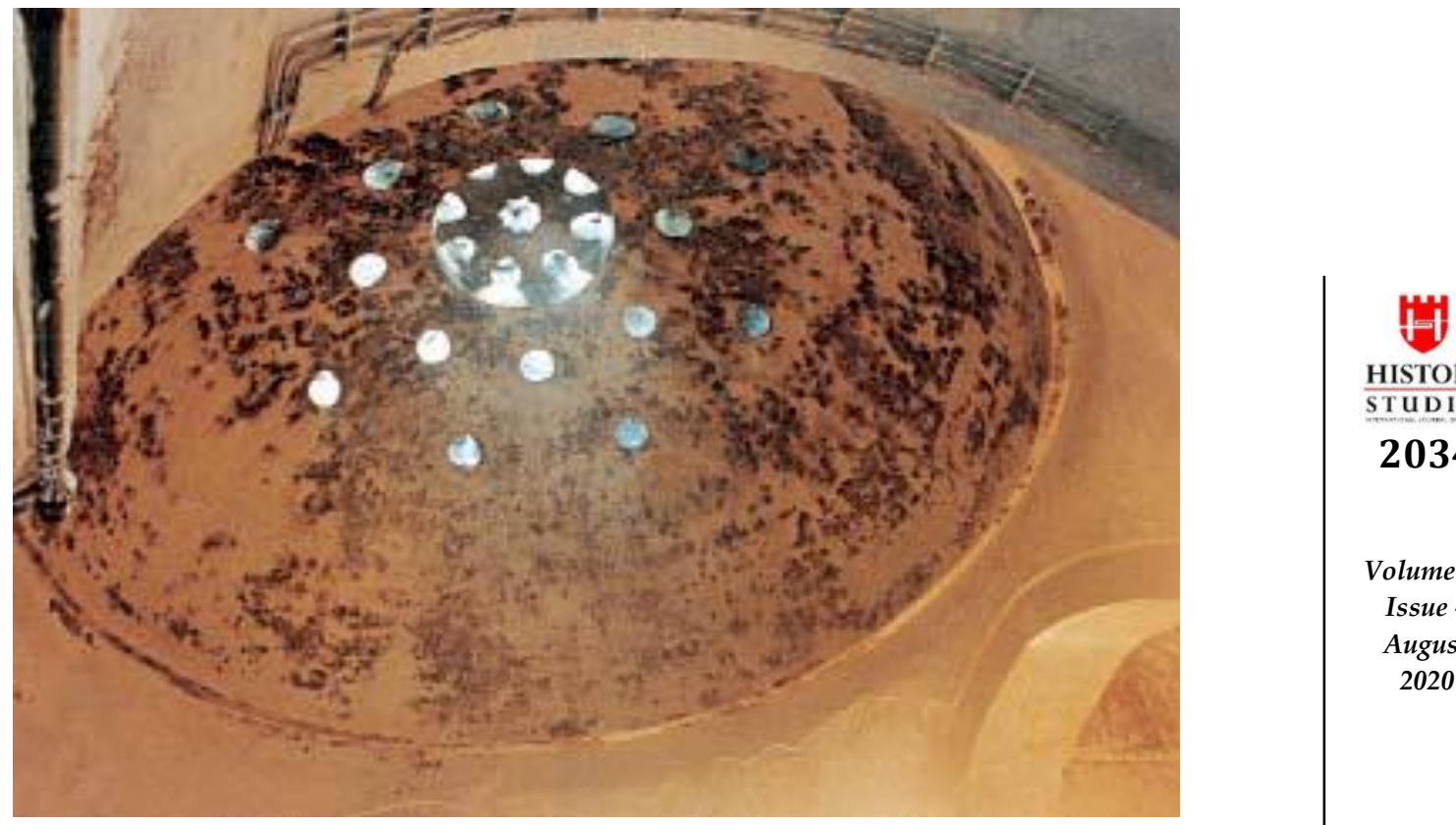

HISTORY

STUDIES

2034

Fotoğraf 4. Selahaddin Hamamı erkekler bölümü sıcaklık kubbesi ${ }^{55}$

\subsection{Kadı Hamamı}

Vakfiye kayıtlarında 1542 'ye tarihlendirilen yapı, çifte hamam olarak inşa edilmiş olup ${ }^{56}$ günümüzde işlevini devam ettirmektedir. Erkekler bölümü soyunmalık mekânının üzerinde sekizgen bir aydınlık feneri bulunmaktadır. Ayrıca giriş kapısının iki kenarına simetrik olarak yerleştirilen ve kubbe trompları içerisinde bulunan dikdörtgen aydınlık pencereleriyle soyunmalığa 1şık alınmaktadır. Soyunmalıktan ulaşılan çamaşırhanenin aydınlatılmasında tonoz üstleri ve sırtlarına yerleştirilen 1şık gözleri kullanılırken, soğukluk ve sıcaklık, kubbe üzerine açılan dairesel formlu aydınlık penceresi ve etrafına yerleştirilen 16'şar adet 1şı gözü ile aydınlatılmaktadır. Soğukluk ve kuzeybatıda bulunan halvet hücresi, tekne tonoz üzerine açılan 8 adet yıldız formlu 1şık gözü ile aydınlatılmakta olup diğer halvet hücrelerinde, sıcaklıkta olduğu gibi üst örtülerdeki aydınlık penceresi etrafına yerleştirilen dairesel formlu 1şık gözleri kullanılmaktadır (Fotoğraf 5).

${ }^{55}$ Age, s. 504.

${ }^{56}$ Age, s. 504. 
Kadınlar bölümü soyunmalık mekânının üst örtüsü betonarmedir. Günümüzde soyunmalık, bu örtü üzerine açılan tepe pencereleri ve güney duvarında yer alan bir aydınlık penceresi ile aydınlatılmaktadır. Soğukluk bölümünün kubbesinde 8 adet dairesel, 2 adet yıldız formlu işık gözü yer almaktadır. Aralık bölümünün aydınlatılması ise tonoz üzerine açılmış altıgen ve yıldız formlu 3 adet 1şık gözü ile sağlanmaktadır. Dikdörtgen formlu sıcaklık bölümünün tonoz örtüsünde 10 adet altıgen formlu 1şı gözü bulunurken, halvet hücrelerinde kubbeler üzerinde yer alan dairesel aydınlık pencereleri etrafına dizilmiş ışık gözleri kullanılmıştır. ${ }^{57}$

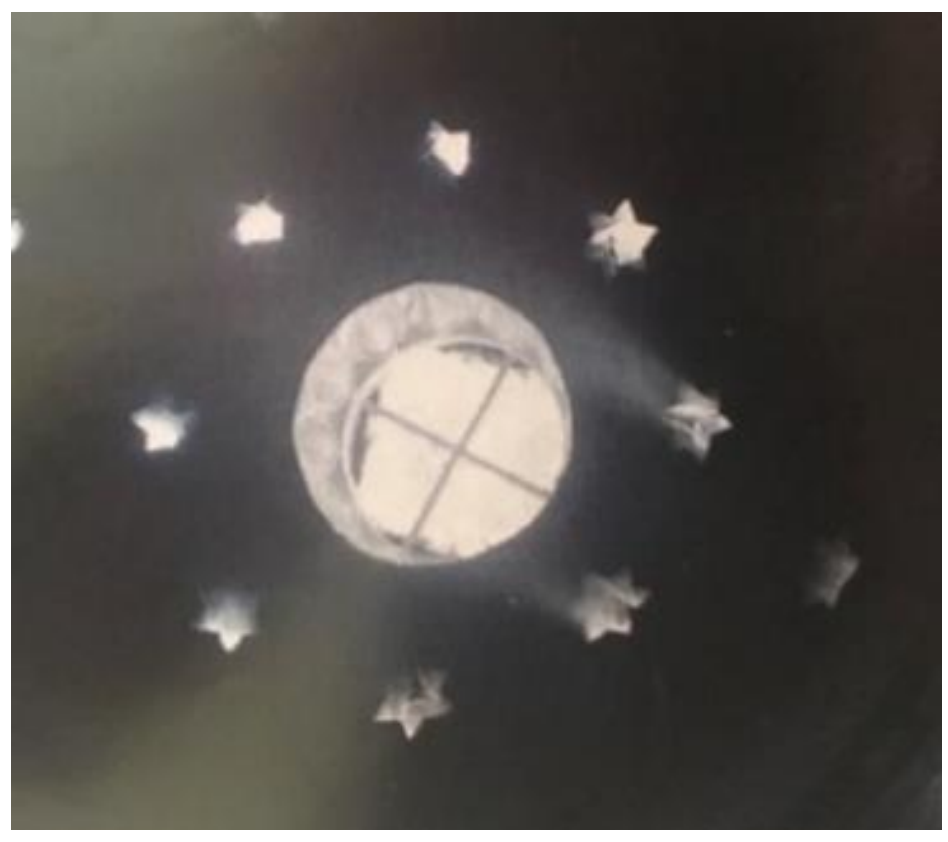

Fotoğraf 5. Kadı Hamamı erkekler bölümü soğukluk kubbesi ${ }^{58}$

\subsection{Cafer Bey Hamamı}

Tek hamam olarak kurgulanmakla birlikte sonradan yapılan onarımlarla çifte hamama dönüştürülen ve 16. yüzyıla tarihlendirilen ${ }^{59}$ yapının erkekler bölümü soyunmalığının üst örtüsü betonarmedir. Güney, doğu ve batı yönündeki aydınlık pencereleri ile 1şık almaktadır. Soğukluk bölümünün aydınlatılması tonoz sırtına açılan 4 adet aydınlık penceresi, sıcaklık bölümünün aydınlatılması ise kubbe üzerindeki dairesel formlu 5 adet 1şı gözüyle sağlanmaktadır. Erkekler bölümünde halvet hücresi bulunmamaktadır.

Ahşap sütunlarla taşıtılan kadınlar bölümü soyunmalığının çatısı, ahşap kirişlerin birbiri üzerine bindirilmesi ile oluşturulan bir kırlangıç örtüyle kapatılmıştır. Örtünün ortasında bir aydınlık feneri yer almaktadır. Soğukluk, tonoz sırtına açılmış 15 adet dairesel ş̧ık gözü ve doğu-batı cephelerindeki aydınlık pencerelerinden 1şık alırken sıcaklığın ve halvet hücrelerinin aydınlatılması, kubbelerin ve tonozların üzerine açılan ışık gözleri ile sağlanmaktadır. ${ }^{60}$

\footnotetext{
${ }^{57}$ Denktaş, age, s. 157

${ }^{58}$ Age, s. 435.

${ }^{59}$ Age, s. 187.

${ }^{60}$ Age, s. 187.
} 


\subsection{Setenönü Hamamı}

17. yüzyıla tarihlendirilen ${ }^{61}$ yapı, son yıllara kadar oldukça harap bir durumda iken günümüzde restorasyonu gerçekleştirilmiş olup henüz bir işlev verilmemiştir. Soyunmalık mekânına, kubbe ortasında yer alan bir aydınlık feneri ve doğu-batı cephelerinde yer alan aydınlık pencereleri ile 1şık alınmaktadır (Fotoğraf 6). Soğuklukta, kubbeler üzerine açılan 1şık gözleri ve doğu-batı cephelerindeki aydınlık pencereleri kullanılırken sicaklık, kubbe eteklerinde ki iki aydınlık penceresi ve kubbe ve tonozlar üzerine açılan ışı gözleri ile, halvet hücreleri ise yine kubbeler üzerine açılan 1şık gözleri ile aydınlatılmaktadır (Fotoğraf 7, 8).

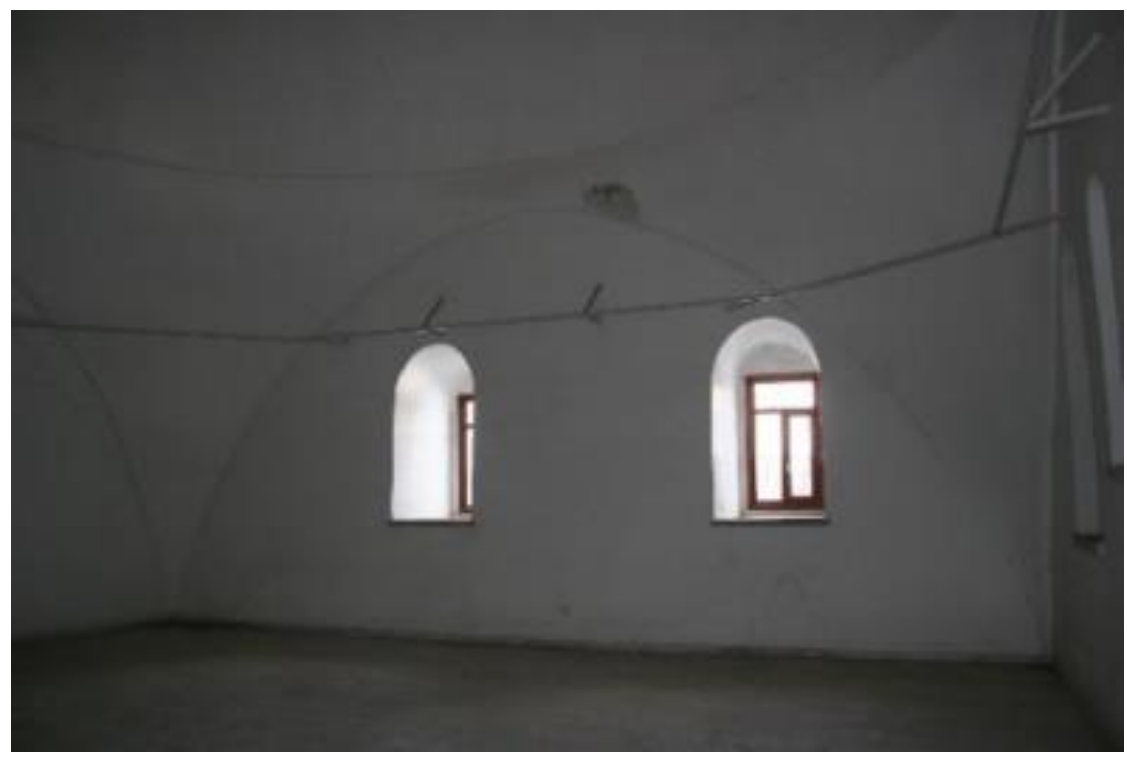

Fotoğraf 6. Setenönü Hamamı soyunmalık bölümü aydınlık pencereleri
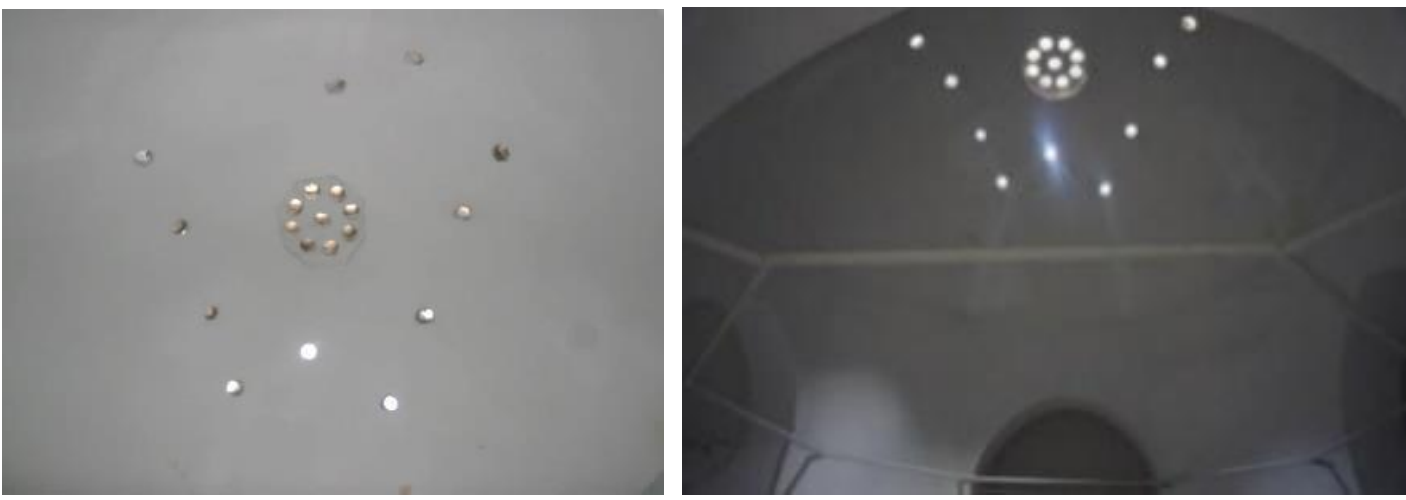

Fotoğraf 7, 8. Setenönü Hamamında 1şık gözlerinin kullanımı

\subsection{Deveci Hamamı}

Tek hamam olarak inşa edilen ancak sonradan çifte hamama dönüştürülen yapı 18. yüzyıla tarihlendirilemektedir. Erkekler bölümü soyunmalığının üst örtüsü betonarme olup üst örtüdeki aydınlatma elemanları hakkında bir bilgi bulunmamaktadır. Soyunmalığın aydınlatılması kuzey

${ }^{61}$ Age, s. 193. 
ve doğu cephelerindeki ikişer adet dikdörtgen aydınlık penceresi ile sağlanırken, soğukluk, sıcaklık ve aralık bölümleri, kubbe ve tonozlar üzerine açılan dairesel 1şık gözleri ile aydınlatılmaktadır. Tuvalet ve aralığın aydınlatılması ise tonoz tepesine açılmış dairesel formlu üç aydınlık penceresiyle sağlanmıştır. ${ }^{62}$ Kadınlar bölümü soyunmalığına, ortadaki aynalı tonozun tepesine ve doğu-batı cephelerine açılan dikdörtgen aydınlık pencereleri ile 1 şı alınmaktadır (Fotoğraf 9). Kubbe ve tonozların üzerinde toplam 17 adet dairesel 1 şık gözü bulunan soğukluk bölümü, ayrıca doğu ve batı cephelerinde yer alan aydınlık pencereleri ile aydınlatılmaktadır. Sıcaklığın ve halvet hücrelerinin aydınlatılması kubbelere açılan 1şık gözleri ile sağlanmaktadır.

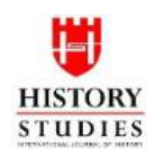

2037

Volume 12

Issue 4

August

2020

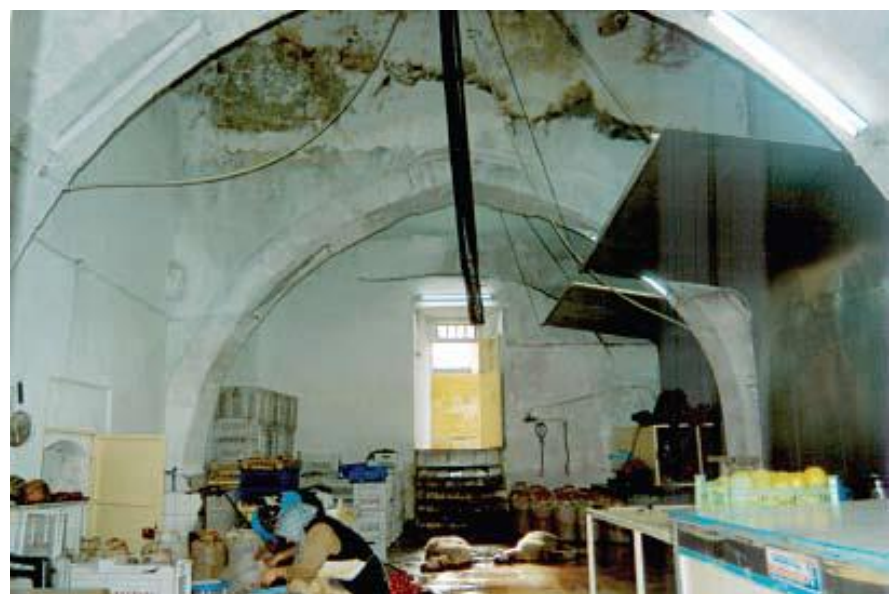

Fotoğraf 9. Deveci Hamamı soyunmalık bölümü ${ }^{63}$

\section{Sonuç}

Elde edilen bulgular incelendiğinde, Selçuklu ve Osmanlı Dönemlerine ait olan bu hamamların aydınlatılmasında dönemsel bir farklılık bulunmadığı görülmektedir. Bölgenin yerel taşları kullanılarak yığma yapım sistemi ile inşa edilen yapılarda yapım tekniği geleneği yerel ustalar aracılığıyla her dönemde devam ettirilmiştir. Ancak yapının büyüklüğüne, önemine veya yaptıran kişinin ekonomik olanaklarına göre üst örtü sisteminin farklı şekillerde kurgulandığı görülmektedir. Daha küçük ölçekli yapılarda ahşap tavan sistemleri de kullanılabilirken büyük ölçekli yapılarda genellikle kubbe ve tonozlar ile kurgulanan üst örtüler görülmektedir. Tipoloji çalışması kapsamında, bu yapı elemanları üzerinde yer alan doğal aydınlatma elemanlarının incelenmesi yapılan mekâna göre aydınlatma elemanlarının çeşitliliği, dağılımı ve formları değerlendirilmiş; aydınlık fenerleri, aydınlık pencereleri (duvara veya tonoz sırtına açılan/ kubbe veya tonoza açılan), 1şı gözleri ve 1şık tavanlarının mekâna göre dağılımları (Tablo 1) ve bu aydınlatma elemanlarının formlarında tespit edilen değişkenlik ve benzerlikler (Tablo 2) sınıflandırılmıştır.

${ }^{62}$ Age, s. 199.

${ }^{63}$ Özbek ve Arslan, age, s. 515. 
Geleneksel Kayseri Hamamlarında Doğal Aydınlatma Sistemleri

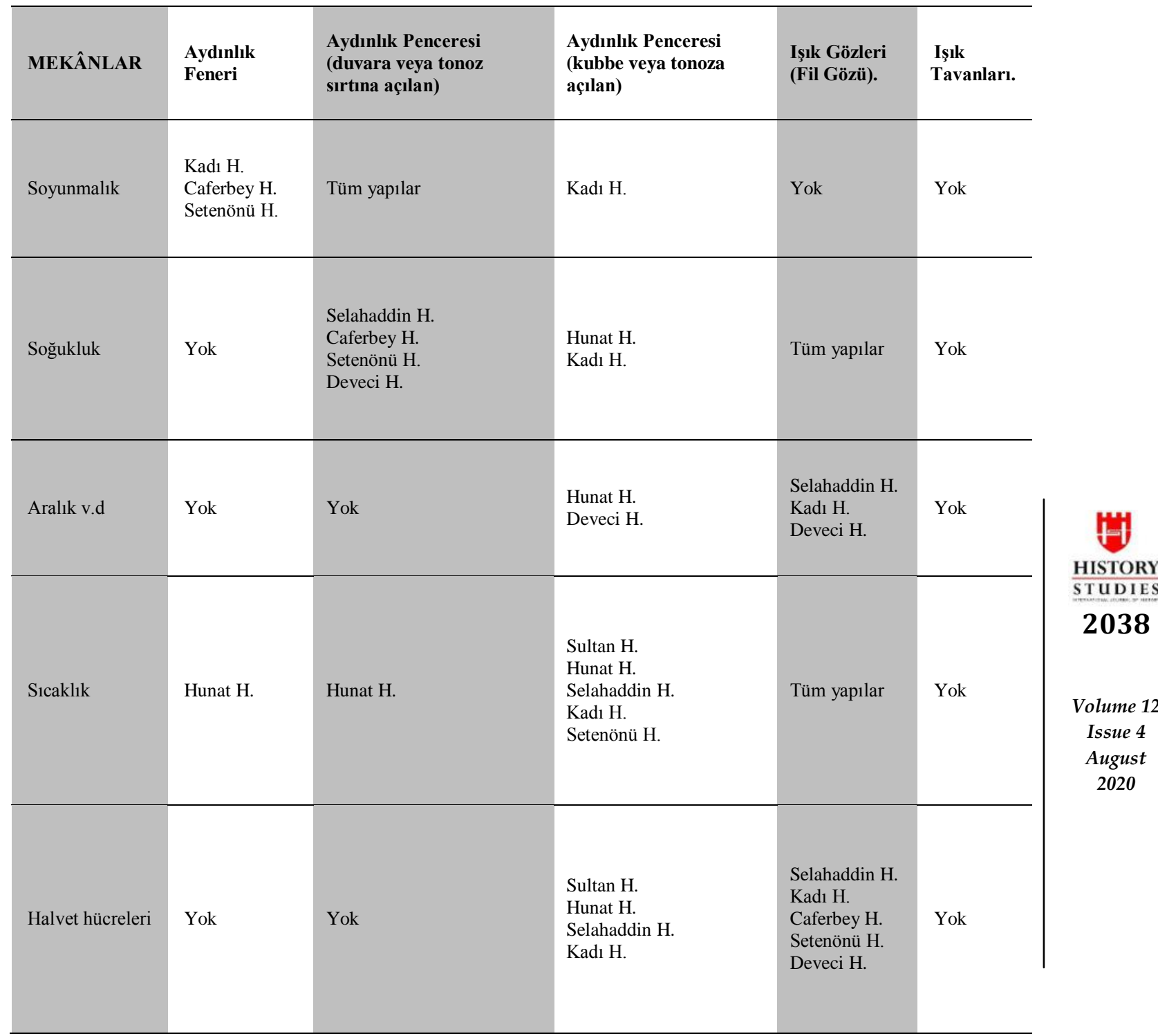

Tablo 1: Kayseri hamamlarında mekâna göre aydınlatma elemanı kullanımı

\begin{tabular}{lllll}
\hline FORMLAR & $\begin{array}{l}\text { Aydınlık } \\
\text { Feneri. }\end{array}$ & $\begin{array}{l}\text { Aydınık Penceresi } \\
\text { (duvara veya tonoz } \\
\text { sırtına açılan) }\end{array}$ & $\begin{array}{l}\text { Aydınık Penceresi } \\
\text { (kubbe veya tonoza açılan) }\end{array}$ & $\begin{array}{l}\text { Işıı Gözleri } \\
\text { (Fil Gözü).. }\end{array}$ \\
\hline Dairesel & $\begin{array}{l}\text { Hunat H. } \\
\text { Setenönü H. }\end{array}$ & Yok & Tüm yapılar & Tüm yapılar \\
\hline \multirow{2}{*}{ Çokgen } & Kadı H. & Yok & Yok & Selahaddin H. \\
& Caferbey H. & & & Kadı H. \\
& & & & Caferbey H. \\
\hline
\end{tabular}


H. Hale Kozlu - Özlem Sümengen - Seven Gözübüyük

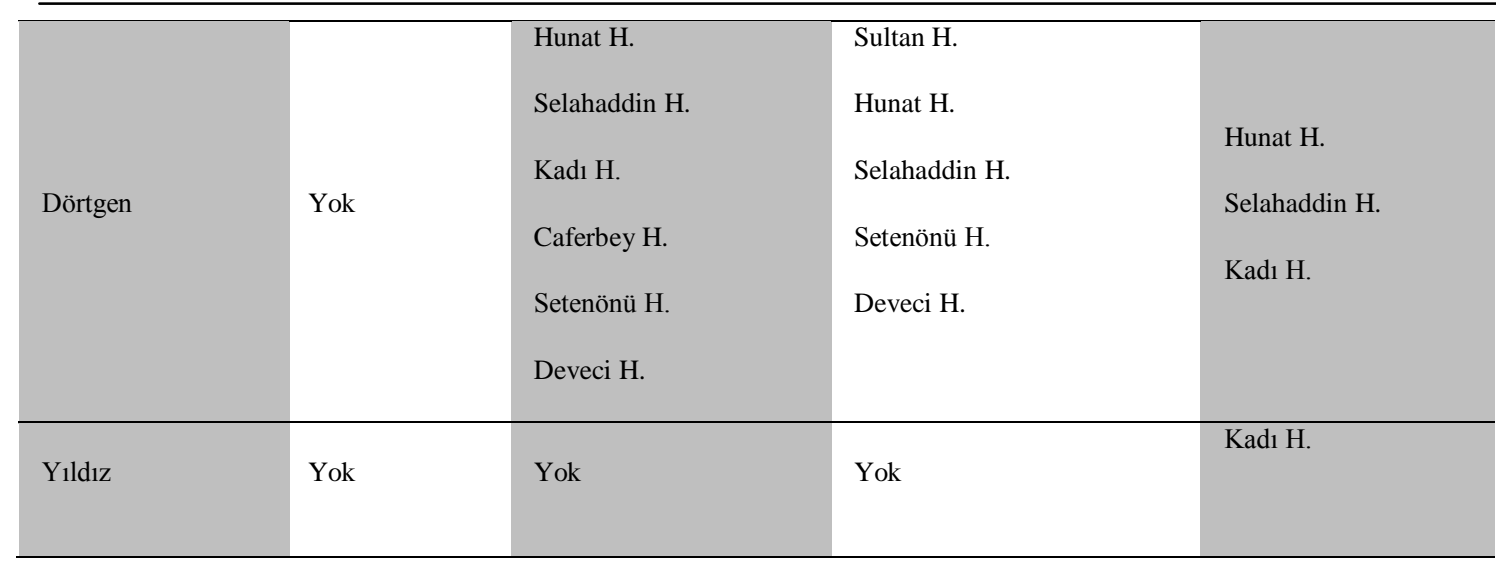

Tablo 2. Aydınlatma elemanlarında kullanılan formlar

Kayseri'de günümüze kadar ulaşabilmiş olan hamamlardaki aydınlatma elemanlarının mekâna göre kullanımları incelendiğinde, yapıların hiçbirinde 1şık tavanı bulunmadığı görülmektedir. Aydınlık fenerleri ise nadiren sıcaklık ve soyunmalık mekânlarında görülmektedir. Bu aydınlatma elemanı sadece Hunat Hamamı sıcaklığı ile Kadı, Cafer Bey ve Setenönü Hamamlarının soyunmalık mekânlarında kullanılmıștır. Hunat ve Setenönü Hamamlarının aydınlık fenerleri çokgen olarak kubbeden yükseltilirken Kadı ve Cafer Bey Hamamlarının aydınlık fenerlerinin dairesel kesitte olduğu görülmektedir. Hamamlarda en sık karşılaşılan aydınlatma elemanı 1şık gözleridir. Tüm yapılarda görülen bu aydınlatma elemanları, çoğunlukla kubbe veya tonoz üzerine açılmakla birlikte bazı örneklerde tonoz sırtlarında da ışı gözlerine rastlanmaktadır. Formları çoğunlukla dairesel olup, tüm yapıların farklı mekânlarında bu formda kullanılmıştır. Yıldız formlu 1şık gözü sadece Kadı Hamamı'nda kullanılmış olup, Hunat ve Selahaddin Hamamlarında dörtgen, Selahaddin, Cafer Bey ve Kadı Hamamlarında çokgen 1şık gözlerinin kullanıldığı görülmektedir. 16. yüzyılda inşa edilen Kadı Hamamı, tüm 1şık gözü tiplerinin aynı anda gözlemlendiği tek hamamdır. Işık gözlerinin kullanımında mekânsal bir ayırım yapılmadığı, soyunmalık, soğukluk, sıcaklık, halvet hücreleri ve aralık gibi servis mekânlarının tamamında veya her yapı için en az birkaç mekânda bu aydınlatma elemanının tercih edildiği gözlemlenmektedir. Bu durum, mekânların işlevleri gereği mahremiyetin sağlanmasının yanı sıra 1şık gözlerinin mekânlara sağladığ 1 estetik ve etkileyici atmosferden kaynaklanmaktadır. Aydınlık pencerelerine de yine hemen hemen her mekânda rastlanmaktadır. Ancak mekâna göre bu pencerelerin yerleri ve büyüklüklerinin değiştiği görülmektedir. Soyunmalık mekânlarında, daha yoğun bir aydınlatmanın sağlanabilmesi için duvarlara açllan daha büyük boyutlu, zaman zaman kemerli dikdörtgen pencereler kullanılırken, diğer mekânlarda; kubbe, tonoz gibi üst örtülere, kubbe eteklerine, tonoz sırtlarına veya duvarların en üst kısımlarına açılan tepe penceresi niteliğinde küçük pencereler yerleştirilmiştir. Duvarlar ve tonoz sırtlarındaki pencere açıklıklarında sadece dikdörtgen veya kare formlar tercih edilirken kubbe ve tonoz üzerindeki açıklıklarda dikdörtgen, kare ve dairesel pencere formların tamamının kullanılabildiği görülmektedir.

Kayseri kenti hamamlarındaki yapma aydınlatma elemanları için geçmişe yönelik belirgin bir veri elde edilememiştir. Yapma aydınlatmanın hem teknolojik gelişime bağlı olması, hem de elektrik kullanımının yaygınlaşması ile değişkenlik göstermesi sebebi ile bu sistemin; günümüzdeki hamam yapılarında sağlıklı bir şekilde analizi yapılamamaktadır.

Doğal aydınlatma sisteminin yapı elemanlarının bir parçası olması nedeniyle günümüze kadar ulaşan yapılarda bu özellikleri tespit edilebilmektedir. Ancak özgün üst örtü sistemi veya duvarları kısmen veya tamamen yok olmuş veya değişmiş olan yapılarda bir restorasyon 
çalışması gündeme geldiğinde, koruma ilkeleri açısından bölgesel bir tipoloji çalışması yapılması zorunludur. Bütünleme veya yeniden yapım gerektiren mekânlardaki açıklıklar konusunda verilecek kararlar, ancak böyle bir tipoloji çalışması sonucunda geliştirilebilir. Kayseri özelinde ise hamamlardaki doğal aydınlatma elemanları için yapılmış bir tipoloji çalışması bulunmamaktadır. Bu tür belgeleme ve tipoloji çalışmaları, mekân ve işlev değerlendirilirken mevcudun tespiti üzerinden yeni öneriler ile birlikte çok yönlü bir bakış açısının geliştirilebilmesinde önemli bir rol oynamaktadır.

Aydınlatma sistemi ve elemanları, yapı kabuğunun iç ve dış arasında geçişi sağlayan, kendine özgü niteliğinin ve işleve uygunluğunun daha da belirginleşerek değerlendirilmesini sağlayan bir parametredir. Hamam yapılarının bölgesel özelliklere göre aydınlatma sistemlerinde tespit edilecek benzerliklerin ve farklılıkların mekânsal etkileri, koruma alanında geliştirilecek yeni önerilerin daha bütünsel ve bilimsel bir ele alışla değerlendirilmesini sağlar. Günümüzdeki teknolojik gelişmeler ve projelendirme aşamasındaki yeni yaklaşımlar göz önünde bulundurulduğunda, aydınlatma sistemine ilişkin öneriler yapıya uygunluk, özgünün korunması, teknolojik yeniliklerin takibi ve görsel konfor koşullarının sağlanması ile birlikte bu yeni önerilerin daha sağlıklı koşullarda geliştirilmesine olanak verir. Bu çalışma ile, Kayseri yöresindeki hamamların restorasyon, yeniden işlevlendirme ve aydınlatma tasarımı çalışmalarında, tespit edilen bu sonuçlardan faydalanılarak hem bilimsel literatüre hem de uygulama alanına katkı sağlanması hedeflenmektedir.

Kaynakça

ABBASOĞLU, Haluk, Pamphylia Bölgesi Roma Devri Hamamları, (İstanbul Üniversitesi Yayımlanmamış Doçentlik Tezi), İstanbul 1982.

AÇICI KURAK, Funda, "Trabzon Türk Devri Yapısı İskender Paşa Cami ve Külliyesi”, Uluslararası Hakemli Tasarım ve Mimarlık Dergisi, S. 10, 2017, s. 275-289.

AKOK, Mahmut , “Çorum'da Ali Paşa Hamamı”, Arkitekt, S. 280, 1955, s. 85-91.

AKURGAL, Ekrem, Ancient Civilizations And Ruins Of Turkey, Haset Kitabevi, İstanbul 1973.

AKURGAL, Ekrem- Max Hirmer, Die Kunst Der Hethiter, Hirmer, München 1976.

ARU, Kemal Ahmet, Türk Hamamları Etüdü, (İstanbul Teknik Üniversitesi Yayımlanmamış Doçentlik Tezi, İstanbul 1949.

ATLI, Süheyla, Mimar Sinan Dönemi Hamamları Konusunda Bir Araştırma, (Mimar Sinan Güzel Sanatlar Üniversitesi Fen Bilimleri Enstitüsü, Yayımlanmamış Yüksek Lisans Tezi), İstanbul 1990.

BAŞGELEN, Nezih v.d., "Bizans İstanbul'u”, İstanbul'un Dört Çă̆l, Ed. Fatma Türe, Yap1 Kredi Yayınları, İstanbul 1999, s. 24-25.

BRÖDNER, Erika, “Zur Entwicklungsgeschichte Des Bades”, Antike Welt, S. 8/4, 1977, s. 4556.

DENKTAŞ, Mustafa, Kayseri'deki Tarihi Su Yapıları (Çeşmeler, Hamamlar), Kıvılcım Yayınları, Kayseri 2000.

EBELING, Erich- Bruno Meissner, Reullexion Der Assyrioligie, W. De Gruyter\&Co., Berlin Und Leipzigg 1928.

ECOCHARD, Michel ve Claude Le Coeur, Les Bains De Damas, C. II, Institut Français, Beyrouth 1943. 
H. Hale Kozlu - Özlem Sümengen - Seven Gözübüyük

ERAT, Birsen, Anadolu'da XIV. Yüzyll Türk Hamam Mimarisi, (Ankara Üniversitesi Sosyal Bilimler Enstitüsü, Yayımlanmamış Doktora Tezi), Ankara 1997.

ERAVŞAR, Osman, "Sultan Hamamı", Selçuklu Gevher Nesibe Sultan Tıp Fakültesi Seтроzуити, Erciyes Üniversitesi Matbaas1, Kayseri 1992, s. 32-35.

ERTUĞRUL, Alidost, "Hamam Yapıları ve Literatürü”, Türkiye Araştırmaları Literatür Dergisi, S. 7/13, 2009, s. 241-266.

EYİCE, Semavi, “İznik’te Büyük Hamam ve Osmanlı Devri Hamamları”, Tarih Dergisi, S. XI, 1960, s. 99-120.

EYİCE, Semavi, "Hamam". Türkiye Diyanet Vakfi İslam Ansiklopedisi., C. 15, Diyanet İşleri Başkanlığı Yayınları, İstanbul 1997, s. 402-430.

GENZMER, Felix, Anlage Und Einrichtung Der Gedaude - Bade Und Schwimmanftalten, J.M. Gebhardt's Verlag, Leipzig 1921.

KLINGHARDT, Karl, Türkische Bader, Mit 85 Abbildungen Und Einer Karte, J. Hoffman, Stutgart 1927.

KUBAN, Doğan, 100 Soruda Türkiye Sanat Tarihi, Gerçek Yayınevi, İstanbul 1981.

NAUMANN, Rudolf, Eski Anadolu Mimarllğı, Türk Tarih Kurumu Basımevi, Ankara 1991.

OKTAÇ, Arife Deniz, Anadolu Türk Mimarisinde Aydınlatma Detayları ve Aydınlatma Elemanları, (Selçuk Üniversitesi Fen Bilimleri Enstitüsü, Yayımlanmamış Yüksek Lisans Tezi), Konya 1992.

Volume 12

ONURKAN, Somay, "Anadolu'da Eski Yunan ve Roma Arkeolojisi”, Anadolu Uygarliklarl, Görsel Anadolu Tarihi Ansiklopedisi, C. 3, Görsel Yayınlar, İstanbul 1985, s. 450-474.

ÖDEKAN, Ayla, "Hamam", Eczacıbaşı Sanat Ansiklopedisi, C. 2, YEM Yayınları, İstanbul 1998, s. 750-753.

ÖGEL, Bahaeddin, Türk Kültür Tarihine Giriş, C. 3, Kültür Bakanlığı Yayınları, Ankara 1978.

ÖNGE, Yılmaz, "Eski Türk Hamamlarında Aydınlatma”., Vakıflar Dergisi, S. 12, 1979, s. 121 137.

ÖNGE, Yı1maz, “Anadolu'da XII-XIII. Yüzyı1 Hamamları Hakkında Genel Bilgiler ve Mimar Koca Sinan'ın İnşa Ettiği Hamamlar”, Mimarbaşı Koca Sinan, Yaşadığı Çă̆ ve Eserleri, C. 1, Ed. Sadi Bayram, T.C Başbakanlık Vakıflar Genel Müdürlüğü Yayınları, İstanbul 1988, s. 404-415.

ÖNGE, Yılmaz, Anadolu'da XII. ve XIII. Türk Hamamları, Vakıflar Genel Müdürlüğü Yayınları, Ankara 1995.

ÖZBEK, Yıldıray ve Celil Arslan, Kayseri Taşınmaz Kültür Varlıkları Envanteri, C. II, Kayseri Büyükşehir Belediyesi Yayınları, Kayseri, 2008.

ŞEHITOĞLU, Elif, Bursa Hamamları, Tarih Vakfi Yurt Yayınları, İstanbul 2006.

TAŞÇIOĞLU, Tülay, Türk Hamamı, TTOK Yayınları, İstanbul 1998.

TURAN, Osman, Selçuklular Tarihi ve Türk İslam Medeniyeti, Türk Kültürünü Araştırma Enstitüsü Yayınları, Ankara 1965.

TURAN, Osman, Selçuklular Zamanında Türkiye, Turan Neşriyat Yurdu, İstanbul 1971. 
ÜLKEN, Hilmi Ziya, İslam Sanatı, İstanbul Teknik Üniversitesi Matbaası, İstanbul 1948.

ÜNSAL, Behçet, Mimari Tarihi, C. 1, İ.T.O. Yayınları, Marifet Matbaası, İstanbul 1960.

YAMAN, Tevfik Cem, Türk Hamamının Mekânsal Kurgusu, İstanbul Hamamları, (Mimar Sinan Güzel Sanatlar Üniversitesi Yayımlanmamış Yüksek Lisans Tezi), İstanbul 2010.

YEGÜL, Fikret, Roma Dünyasında Yıkanma, Koç Üniversitesi Yayınları, İstanbul 2010.

YILMAZ, İbrahim, "Kırşehir'de Selçuklu Dönemine Ait Bir Yap1 Karakurt Han-Ilıcası", Uluslararası Hakemli Tasarım ve Mimarlık Dergisi, S.10, 2017, s. 56-79.

YURDAKUL, Erol, "Son Buluntulara Göre Kayseri'de Hunat Hamamı”, Selçuklu Araştırmaları Dergisi, S. II, 1971, s. 141-151 